\title{
Pembentukan Kader Remaja New Normal Dusun Mayungan II dan Karanganyar, Sanden, Bantul
}

\author{
Suryani Hutomo ${ }^{1}$, Christiane Marlene Sooai ${ }^{1}$, Maria Silvia Merry ${ }^{1}$, Haryo Dimasto Kristianto ${ }^{1}$, Novika \\ Kurniawati ${ }^{2}$ \\ \#1. Fakultas Kedokteran Universitas Kristen Duta Wacana, Yogyakarta \\ 2. Puskesmas Sanden, Bantul
}

${ }^{1}$ suryani_hutomo@staff.ukdw.ac.id ; christiane_sooai@staff.ukdw.ac.id ; dr.silvia.clinmic@gmail.com ; haryodimasto@staff.ukdw.ac.id ${ }^{2}$ vicha2302@gmail.com

\begin{abstract}
Abstrak-Pandemi COVID-19 yang telah berlangsung lebih dari satu tahun membuat semua orang mengalami kendala untuk menjalani kehidupan normal seperti sediakala. Meskipun demikian, kehidupan normal harus dapat dilakukan kembali dengan menerapkan protokol kesehatan untuk pencegahan penularan COVID-19. Tujuan Pengabdian Kepada Masyarakat ini adalah untuk melatih kader remaja agar bisa mendampingi dan memberi contoh kepada warga di sekitar tempat tinggalnya melaksanakan protokol kesehatan dalam kehidupan sehari-hari. Metode yang dipakai adalah ceramah, diskusi, dan praktik dalam kelompok kecil, dilanjutkan melaksanakan tugas berupa sosialisasi materi pelatihan di wilayah tempat tinggalnya. Pada evaluasi 2 minggu setelah pelatihan, dilaporkan bahwa kader sudah melaksanakan tugas dan materi yang disampaikan dapat diterima dengan baik oleh masyarakat. Masyarakat mengharapkan kegiatan kader terus berlanjut dan para kader mengusulkan supaya diadakan pelatihan lanjutan untuk meningkatkan pengetahuan dan keterampilan mereka
\end{abstract}

Kata kunci- kader remaja, new normal, protokol kesehatan, pencegahan penularan

Abstract-The COVID-19 pandemic, which has lasted more than a year, has made it difficult for everyone to live a normal life as usual. Nevertheless, normal life must be resumed by implementing health protocols to prevent the transmission of COVID-19. The aim of this Community Service was to train youth volunteers in order to be able to accompany and set an example for residents around their surrounding environment to implement health protocols in their daily lives. The method used are through discussion talk and practice in small groups, followed by carrying out tasks in the area where their lives. In the two weeks evaluation after the training, it was reported that the youth volunteers had carried out their duties and were well received by the community. The community really expects that these activities will be continued and the youth volunteers propose a suggestion for further training in order to improve their knowledge and skills.

Keywords - youth volunteers, new normal, health protocol, prevention of transmission

\section{PENDAHULUAN}

Dalam rangka terlaksananya rencana pembangunan jangka panjang nasional, sumber daya manusia merupakan

subyek penting dalam pembangunan. Saat ini bangsa Indonesia sedang menghadapi tantangan yang mengharuskan sumber daya manusia beradaptasi dengan situasi pandemi Corona Virus Disease 2019 (COVID-19). Pemerintah telah mengimbau agar masyarakat bersiap untuk memasuki masa new normal atau hidup "berdampingan" dengan COVID-19 sambil menjalani aktivitas seperti biasa. Hal ini mendorong kita untuk lebih gencar memberikan pengetahuan pada masyarakat tentang penyakit yang disebabkan oleh infeksi virus tersebut serta upaya promotif dan preventif kepada masyarakat dalam menerapkan langkah pencegahan dasar untuk mencegah penularannya. Langkah-langkah pencegahan dasar terdiri dari mencuci tangan dengan sabun dan air mengalir atau dengan hand sanitizer, tidak menyentuh wajah dengan tangan yang belum dicuci, menerapkan physical distancing, serta mengenakan masker dalam setiap aktivitas, terutama di tempat umum dan menjaga daya tahan tubuh agar tetap sehat. Hal ini tertuang dalam Surat Keputusan Menteri Kesehatan nomor HK.01.07/Menkes/382/2020 tentang Protokol Kesehatan Bagi Masyarakat di Tempat dan Fasilitas Umum Dalam Rangka Pencegahan dan Pengendalian COVID-19 [1]

Penerapan protokol kesehatan yang belum optimal di masyarakat menjadi salah satu penyebab meningkatkan kasus COVID-19 [2]. Data kasus nasional bulan Juni 2021 menunjukkan masih tingginya jumlah penderita COVID-19. Di Daerah Istimewa Yogyakarta dilaporkan terdapat 46.977 penderita COVID19. Dari jumlah tersebut di Kabupaten Bantul terdapat 14.921 penderita. Bila dibandingkan dengan KapanewonKapanewon di Kabupaten Bantul, Kapanewon Sanden merupakan daerah dengan jumlah penderita cukup rendah 
yaitu terdapat 457 kasus dengan 26 kasus aktif [3]. Berdasarkan hal tersebut, dipilih Sanden sebagai tempat melaksanakan kegiatan Pengabdian Masyarakat ini, agar upaya pencegahan dapat diterapkan sejak dini dan angka kasus dapat ditekan.

\section{PERMASALAHAN}

Permasalahan yang dihadapi masyarakat adalah belum dilaksanakannya protokol kesehatan secara benar dan rutin. Di samping itu, beredarnya berbagai informasi di kalangan masyarakat yang belum tentu benar, berupa disinformasi atau hoax. Menurut beberapa penelitian, hoax dan disinformasi itu dapat menurunkan kepatuhan seseorang terhadap protokol Kesehatan, sehingga menghambat penekanan laju kasus [4], [5]. Melihat hal tersebut, Pusat Studi Penyakit Tropis dan Infeksi Fakultas Kedokteran Universitas Kristen Duta Wacana (PS-PTI FK UKDW) bekerjasama dengan Puskesmas Sanden menyelenggarakan kegiatan promotif dan preventif berupa pengabdian pada masyarakat dengan membentuk Kader Remaja New Normal Dusun Mayungan II Murtigading dan Dusun Karanganyar Gadingharjo Sanden Bantul Yogyakarta untuk mencegah penularan virus Corona sekaligus menerapkan Perilaku Hidup Bersih dan Sehat (PHBS).

\section{METODE PELAKSANAAN}

Observasi lapangan dilakukan oleh tim PS-PTI FK UKDW bersama tim Puskesmas Sanden untuk menentukan dusun yang akan dibina sebagai percontohan. Observasi dilakukan dengan cara mengirimkan kuesioner ketertarikan dan keinginan untuk dilatih sebagai kader kepada anggota Karang Taruna dusun. Dusun Mayungan II, Murtigading dan Dusun Karanganyar, Gadingharjo dipilih sebagai dusun percontohan karena jumlah peminat yang paling banyak dan berkomitmen untuk melaksanakan tugas dengan baik.

Kerangka Acuan Kegiatan disusun oleh Penanggungjawab Upaya Puskesmas bersama tim FK UKDW. Pembuatan modul pelatihan dilakukan sebelum kegiatan pelatihan berjalan. Diharapkan modul dapat menjadi pegangan bagi para peserta pelatihan. Rencana program kegiatan disosialisasikan terlebih dahulu kepada Kepala Dusun Mayungan II, Kepala Desa Murtigading, Kepala Dusun Karanganyar, Kepala Desa Gadingharjo serta pihak Kepanewon Sanden dan mendapatkan persetujuan.

Kegiatan sosialisasi dilaksanakan di Aula Puskesmas Sanden. Pembinaan, pemantauan dan evaluasi dilaksanakan secara bertahap. Kegiatan berlangsung dari bulan Juni sampai dengan Desember tahun 2021. Pada awal tahun 2022 diharapkan masyarakat sudah dapat melaksanakan Protokol Kesehatan secara benar dalam kehidupan seharihari secara mandiri. Di samping itu angka kejadian penderita COVID-19 juga diharapkan sudah semakin menurun. Adapun rincian kegiatan pembentukan dan pembinaan Kader Remaja New Normal adalah sebagai berikut:

\section{A. Pembentukan dan pembinaan Kader Remaja New Normal}

Kegiatan dilaksanakan pada hari Kamis 10 Juni 2021, jam 08.30 WIB sampai selesai, bertempat di aula Balai Desa Murtigading. Penyampaian materi berupa ceramah, demonstrasi dan diskusi. Peserta terdiri dari perwakilan masing-masing 10 orang kader remaja Mayungan II dan Karanganyar, petugas puskesmas pendamping dusun (Gasbinsun) dan bapak Dukuh sebagai penanggungjawab kegiatan di pedukuhan. Acara dibuka dengan pemaparan Kepala Puskesmas tentang kondisi dan sebaran COVID-19 di Kapanewon Sanden. Materi yang pertama adalah pemahaman Sars CoV-2 dan COVID-19 secara benar, disampaikan oleh dr. Maria Silvia Merry, MSc. Materi ini menjelaskan tentang pengertian, tanda dan gejala serta faktor-faktor penyebab keparahan infeksi virus SARS CoV 2 sebagai penyebab COVID-19 Pada materi tersebut dijelaskan pula jenis-jenis pemeriksaan yang harus dilakukan bila gejala muncul [6], [7]. Pentingnya dilakukan vaksinasi serta bagaimana vaksin bekerja dalaam tubuh juga dijelaskan pada materi ini [8], [9]

Materi kedua tentang infeksi bakteri dan jamur disampaikan oleh Dr drg MM Suryani Hutomo MDSc. Pada materi kedua dipaparkan tentang adanya infeksi-infeksi lain yang disebabkan oleh bakteri dan jamur yang juga harus diwaspadai. Sebagai contoh, saat ini masih ditemukan penderita penyakit TBC yang disebabkan oleh bakteri Mycobacterium tuberculosis. Penyakit TBC berbahaya karena sangat menular dan dapat menyebabkan kematian bila tidak diobati secara benar [10]. Infeksi bakteri lain yang juga berbahaya adalah demam tifoid yang disebabkan oleh Salmonella typhi. Demam tifoid merupakan infeksi usus dengan gejala demam, sakit perut, sembelit dan mual. Pada infeksi tifoid, bakteri masuk ke dalam tubuh melalui makanan. Infeksi yang juga dibahas adalah infeksi jamur. Jamur biasanya menyerang kulit. Contoh infeksi yang disebabkan jamur adalah panu, kadas dan kurap. Infeksi jamur dapat dihindari dengan menjaga kebersihan tubuh, tidak bertukar handuk dan pakaian dengan orang lain, serta memakai pakaian yang bersih setiap hari

Materi ketiga tentang infeksi parasit disampaikan oleh dr Christiane Marlene Sooai, MBiomed. Parasit berukuran lebih besar dari bakteri virus dan jamur. Salah satu contoh hewan parasit adalah cacing. Infeksi cacing dalam tubuh manusia disebut cacingan. Ada tiga kelompok cacing yang dapat menginfeksi manusia, yaitu: Platyhelminthes atau cacing pipih, Acanthocephalins, yang umumnya menyerang sistem pencernaan manusia dan Nematoda, yang dapat menyerang saluran gastro-intestinal, darah, sistem limfatik, dan jaringan subkutan manusia. Cacing ini sering ditemukan pada hewan peliharaan, misalnya anjing dan kucing. Hewan peliharaan tersebut kemudian dapat 
menularkan infeksi cacing pada manusia. Gejala yang ditimbulkan antara lain adanya cacing dalam feses, mengalami diare atau sakit perut selama lebih dari dua minggu, terkadang juga terdapat keluhan konstipasi/ sembelit [11].

Materi keempat adalah tentang pentingnya Perilaku Hidup Bersih dan Sehat (PHBS) pada keluarga, disampaikan oleh dr. Haryo Dimasto Kristyanto. Ada 10 kriteria PHBS tatanan rumah tangga meliputi: persalinan ditolong oleh petugas kesehatan, bayi diberikan ASI eksklusif, balita ditimbang secara teratur, menggunakan air bersih, mencuci tangan dengan air bersih dan sabun, menggunakan jamban sehat, memberantas jentik nyamuk, makan buah dan sayur, melakukan aktivitas fisik serta tidak merokok di dalam rumah. Dengan melakukan PHBS juga dapat mencegah resiko terjadinya penyakit dan melindungi diri dari ancaman penyakit, terutama penyakit infeksi [12]. Dalam kondisi pandemi COVID-19 ini, pengembangan dari PHBS adalah Gerakan $5 \mathrm{M}$ yang merupakan langkahlangkah pencegahan dasar terhadap infeksi COVID-19. Gerakan 5M terdiri dari mencuci tangan dengan sabun dan air mengalir atau dengan hand sanitizer, menjaga jarak dengan menerapkan physical distancing, mengenakan masker dalam setiap aktivitas, terutama di tempat umum, menjauhi kerumunan dan membatasi mobilitas [13]. Pada sesi keempat ini dilakukan demo mencuci tangan dan memakai masker dengan benar yang dipandu oleh mahasiswa dan diikuti oleh seluruh peserta.

Materi kelima tentang pentingnya aktivitas fisik dimasa pandemi disampaikan oleh Novika Kurniawati, SSi. Aktifitas fisik dan olahraga rutin dengan cara yang tepat perlu dilakukan untuk meningkatkan imunitas tubuh. Aktifitas ini dapat dilakukan di rumah. Aktifitas fisik yang disarankan adalah aktifitas dengan intensitas sedang dan menghindari intensitas tinggi. Waktu yang dianjurkan untuk melakukan aktifitas fisik adalah 30 menit secara teratur setiap hari. Disarankan untuk melakukan peregangan atau berjalan kaki [14], [15]
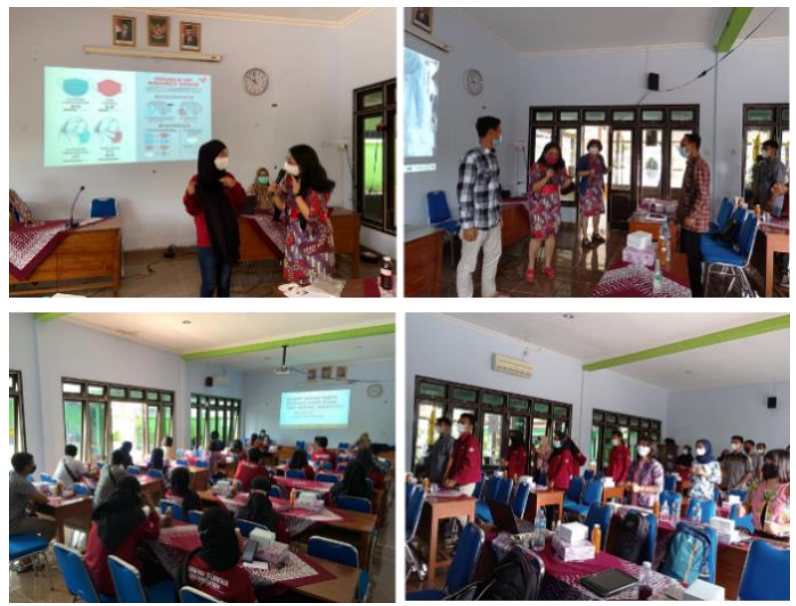

Gambar 1. Suasana pelatihan kader remaja. Acara dibuat sesuai dengan protokol kesehatan, cuci tangan sebelum masuk ruang pelatihan, semua peserta dan pemateri memakai masker, duduk berjarak

\section{B. Hasil dan Pembahasan}

Pelaksanaan pembekalan para kader normal baru sesuai dengan target yang dicapai. Pada rapid assessment sesi pertama yang disampaikan oleh dr. Maria Silvia Merry, MSc dengan 10 pertanyaan betul salah terkait dengan pengetahuan dasar COVID-19, nampak kenaikan $65 \%$ nilai pretest dan post test. Para peserta juga dapat menjawab pertanyaan yang dilontarkan pemateri secara lisan dengan benar. Hal tersebut juga nampak pada sesi-sesi berikutnya.

Setelah sesi, para kader remaja telah melaksanakan tugas-tugas mereka sesuai dengan kesepakatan setelah pelatihan. Kegiatan-kegiatan yang mereka lakukan antara lain penyemprotan tempat ibadah dan lingkungan, edukasi menggunakan masker dengan benar dan mencuci tangan. Para kader membuat inovasi pemantauan penerapan protokol kesehatan pada acara hajatan dengan menyiapkan tim pemantauan.
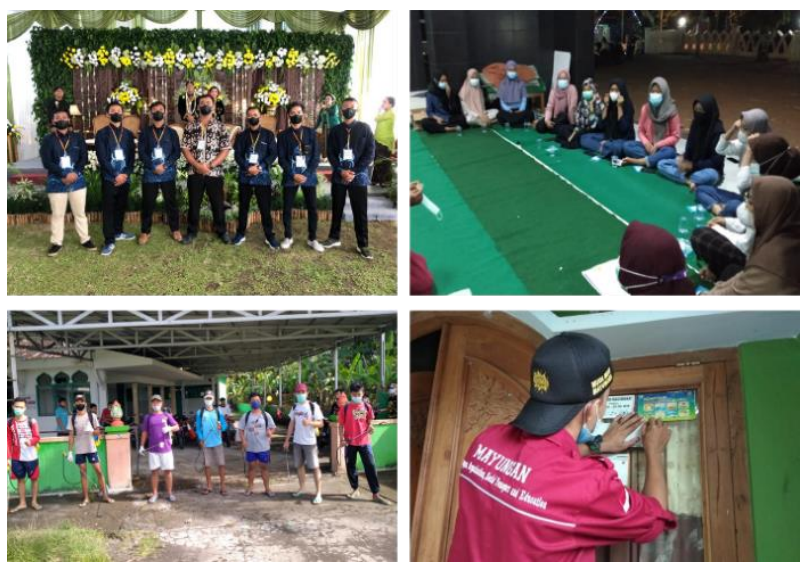

Gambar 2. Kegiatan yang dilakukan para kader remaja di masyarakat

Saat ini kita sedang fokus melakukan berbagai upaya pencegahan COVID-19. Meskipun demikian, berbagai penyakit infeksi masih banyak terjadi di Indonesia. Di masa pandemi COVID-19 ini perlu juga diwaspadai penyakitpenyakit infeksi yang lain. Sebagai contoh, tuberkulosis masih merupakan masalah kesehatan utama di Indonesia. Diperkirakan saat ini terdapat 845 ribu kasus baru dari penyakit menular ini yang seharusnya ditemukan, tetapi hanya terdapat 350 ribu yang terlaporkan. Pencegahan infeksi tuberkulosisi ini sama dengan pencegahan COVID19, yaitu dengan memakai masker secara benar dan menjaga jarak [10] Dengan menerapkan protokol kesehatan secara benar diharapkan penularan TB juga dapat dicegah.

Cacingan merupakan penyakit menular yang juga masih menjadi masalah kesehatan masyarakat di Indonesia karena 
masih banyak terjadi di seluruh wilayah di Indonesia. Infeksi cacing ini mengakibatkan menurunnya kondisi kesehatan, kecerdasan dan produktivitas. Dalam upaya reduksi kecacingan pada masyarakat terutama pada kelompok balita dan anak usia sekolah perlu dilakukan peningkatan pemberdayaan masyarakat dan komitmen lintas program dan lintas sektor [11].

\section{KESIMPULAN}

Kader remaja dapat menangkap materi yang diberikan dan sudah meneruskan wawasan informasi yang didapatkan kepada masyarakat. Penyampaian dari kader remaja tersebut diterima dengan baik oleh masyarakat. Sebagai masukan dan tanggapan, masyarakat mengharapkan kegiatan kader terus berlanjut dan para kader mengusulkan supaya diadakan pelatihan lanjutan untuk meningkatkan pengetahuan dan keterampilan mereka.

\section{UCAPAN TERIMA KASIH}

Kepala Dusun Mayungan II, Kepala Desa Murtigading, Kepala Dusun Karanganyar, Kepala Desa Gadingharjo serta pihak Kepanewon Sanden, Kepala Puskesmas Sanden, dan pihak dekanat FK UKDW yang telah mendukung terlaksananya kegiatan pengabdian masyarakat ini.

\section{DAFTAR PUSTAKA}

[1] MENTERI DALAM NEGERI REPUBLIK INDONESIA INTRUKSI MENTERI DALAM NEGERI NOMOR 4 TAHUN 2020. 2020 , p. 7.

[2] KEMENTERIAN KESEHATAN REPUBLIK INDONESIA, "Kepatuhan Masyarakat Terhadap Protokol Kesehatan Belum Optimal," 2020

https://www.kemkes.go.id/article/view/20062200002/kepatuha n-masyarakat-terhadap-protokol-kesehatan-belumoptimal.html.

[3] Puskesmas Sanden, "SISTEM PECATATAN DAN PELAPORAN TERPADU PUSKESMAS LAPORAN BULANAN," Bantul, 2021.

[4] S. Tasnim, M. Hossain, and H. Mazumder, "Impact of rumors and misinformation on COVID-19 in Social Media," J. Prev. Med. Public Heal., vol. 53, no. 3, pp. 171-174, 2020, doi: 10.3961/JPMPH.20.094.

[5] N. M. Nasir, B. Baequni, and M. I. Nurmansyah, "Misinformation Related To Covid-19 in Indonesia," J. Adm. Kesehat. Indones., vol. 8, no. 2, p. 51, 2020, doi 10.20473/jaki.v8i2.2020.51-59. 